\title{
Rubbish, Recycling and Religion: Indonesia's Plastic Waste Crisis and the Case of Rumah Kompos in Ubud, Bali
}

\author{
Michael S Northcott \\ Indonesian Consortium for Religious Studies (ICRS), Universitas Gadjah Mada, Yogyakarta, \\ Indonesia \\ $<$ m.s.northcott@gmail.com>
}

\begin{abstract}
Indonesia is the second largest global source of marine plastic after China. Plastic waste, together with toxic smoke from extensive unregulated rubbish burning in homes and businesses, are grave public health threats in Indonesia. This paper presents a case study in Ubud, Bali of a community-based recycling and waste sorting project - Rumah Kompos -which demonstrates the potential of religious wisdom and belief to contribute to help solve Indonesia's waste problem. The cultural role of religions in the case study is part of a larger Indonesian, and world religions, phenomenon in which churches, mosques and temples, and faith-based schools (and in Indonesia Islamic boarding schools or pesantren) have made efforts to sponsor pro-environmental behaviours at local community level. The paper also recalls the relevance of anthropological studies of religion, especially Mary Douglas'classic study Purity and Danger, in understanding the connected genealogies of waste and religion. Douglas theorises that identification and regulation of hazardous and 'polluting' practices, concerning bodily fluids, food, clothing, housing, habitable land, potable water and sexual relationships was central to the social role of traditional religions. The disturbance to this long-established function of religion occasioned by the speed and scale of adoption of modern technological innovations, and of a modern 'consumer lifestyle', points to an under-studied dialectic between religion and waste which, in a nation as religiously active as Indonesia, ought to be included in both the conceptualisation of, and policy-making concerning, plastic and waste management.
\end{abstract}

Keywords: religion, recycling, waste, management, community

Indonesia is the second largest national source of marine plastic after China, and in 2010 was estimated to emit between 0.5 and 1.3 million tonnes of plastic debris into the oceans annually. This finding was based on data on plastic usage and data on the percentage of 'mis-managed' plastic (plastics that 
escape waste collection procedures)

which in Indonesia is estimated at $83 \%$.

[1] This rate of mismanagement reflects the fact that neither national nor local governmental institutions provide rubbish disposal mechanisms - such as close waste receptacles, mechanical dump trucks, and waste sorting depots - of the kind that are common in more developed Asian nations including South Korea and Singapore. The finding was challenged by the Indonesian government, but it has now commissioned its own data gathering exercise on waste plastic to inform a Presidential decree of 2018 which, in recognition of the unmanaged nature of the problem, set the national goal of reducing marine plastic debris by $70 \%$ by 2025.[2]

As an instance of the problem of marine debris, the author made an informal visual survey of three beaches on the shoreline facing Lombok on the Southwestern shore of Sumbawa during the monsoon in February 2020 over five days. Plastic discarded in water catchments in the dry season which on Lombok in 2019 lasted for seven months - is washed by rain from streams into rivers and then the ocean during the rainy season which usually from December to February, though the onset of which was delayed in 2019/20. On Southwest Sumbawa significant quantities of plastic was evident in floating rafts on the sea surface behind breaking waves just offshore, while heavier plastic debris rode in with waves, to be deposited at high tide mixed in with waste wood including sawn logs and bamboo, timber offcuts and old coconuts. Plastic was also widely evident under the surface, especially snagged on remaining coral reef.

The most common constituents of floating and beach plastic debris included oil containers, Styrofoam insulation materials and food containers, discarded footwear, food wrappings - especially single use sachets for instant mee, coffee, kropok, ketchup and so on, toothpaste tubes, plastic bags, cosmetic bottles such as hair shampoo, plastic straws, broken blown foam interiors of surf boards, and lastly water bottles. There were relatively few water bottles which is because there is a higher collection price on these than other kinds of plastic and so they are more reliably collected by pemulung informal low income street collectors or 'scavengers' in Bali and Lombok. [3] Contaminated and mixed plastics, such as food wrappings, cosmetic and oil containers, are of lower or no value to the principal Indonesian plastic recycling facilities so middle men offer a lower price for these to pemulung.[4]

The Southwest beaches of Sumbawa have reliable surfing 'breaks' and so are attractive to surfers but the plastic is off-putting and combined with waste wood poses a danger to swimmers and surfers. Hence the tourist 
businesses located by the beaches make efforts to deal with the problem. On Sunday, 23 February 2020, managers of two of the businesses arranged with their staff a gotong royong (communal voluntary work) of the beach in which both plastic waste and wood debris were gathered into piles and burned, some in a large upturned concrete pipe of the kind used in many Indonesian homes as a backyard waste burner, and in which larger plastic items would explode when alight. The rest was burned in piles of wood and plastic arranged in a row above the high tide line and marked off with upturned sticks. The consequence of the gotong royong was a visually cleaner beach, and significantly reduced floating plastic in the ocean. But smoke from the fires hung low over the beach for two days after the burning.

The toxicity of smoke from open burning of waste is well established scientifically, although evidence from informal conversations by the author with Indonesian householders indicates that awareness of its negative health affects is very low. A recent review of the scientific evidence indicates that smoke from waste fires typically contains dioxins, bisphenols, benzene, black carbon, carbon monoxide and other noxious compounds - many of them known carcinogens - together with particulates PM 2.5 and PM 10, and that inhalation of these 'increases the risk of heart disease, aggravates respiratory ailments such as asthma and emphysema and rashes, nausea or headaches, and damages the nervous system.' [5] Ash and soot from burning rubbish are also carried by the wind onto fields and open water and toxic substances including heavy metals and Volatile Organic Compounds leach into groundwater, soils and, ultimately, the plants, fish and animals which humans eat.[6]

Marine plastics is a global problem, public awareness of which grew significantly through media exposure, particularly David Attenborough's 2018 Blue Planet II series. Marine, riverine and soil deposition of plastic is not confined to developing countries, but is rather an intrinsic consequence of the growth in industrial production of plastic which, from 1950 to 2015, generated 6,300 million metric tonnes of plastic of which approximately $12 \%$ was burned, $9 \%$ recycled, with the rest being either deposited in landfill or washed into rivers and thence the oceans.[7] Some argue that the generation of huge quantities of waste and its deposition in the earth and oceans, is not only a feature of the plastics industries but an intrinsic feature of industrial capitalism and consumerism.[8] Others argue - and these include the religious leader Pope Francis in his 'ecological' encyclical Laudato 'Si: On Care for Our Common Home - that it is both desirable and technically feasible to re-design and transform contemporary industrial 
capitalism by the planned adoption of a 'circular economy' in which what industry makes, synthesises, transforms and ultimately 'wastes' in the processes of production and consumption is taken back into productive processes for reuse at the end of its product life.[9]

The phrase 'circular economy' has a range of different meanings and the quantity of waste materials that humans currently generate in their lifetimes would indicate that there will always be waste needing to be buried or burned, as well as reusable materials, and indeed there has always been waste, as the archaeology of waste demonstrates. [10] But the critical issue with plastics is their toxicity both to humans and otherkind. With plastics and its uses it is reasonable to say that some version of a circular approach to the products for which plastics are currently used ought urgently to be regulated for by governments, commencing with bans on all single use plastics, and not just straws and plastic bags, combined with the simultaneous development of non-toxic substitutes such as readily compostable packaging, and the design and production of artefacts from nonmineral oil sources such as algae, cassava, leaf matter and wood fibre.

The significant extent of solid waste mis-management in Indonesia is in part a function of the rapid increase in plastics production, sale and use since the 1970s which were heavily promoted by corporate actors in Indonesia, as in other nations, as a means for increasing surplus accumulation without regard to social costs.[11] The speed and quantity of plastics now in daily use in Indonesia have overwhelmed the traditional village-based and informal waste collection practices on which Provinces (local government regions across Indonesia's seventeen thousand islands) in both rural and urban areas continue to rely. There is a particular irony in Indonesia, and other tropical countries, in that plastics are now utilised on a huge scale to replace serviceable, and yet compostable, materials that performed the same functions as plastic but which were derived from locally grown materials including most notably bamboo, banana and palm branches, shells, husks and leaves. Disposal on the ground where they are exposed to heat and moisture did not represent a hazard since in tropical climates these plantbased materials rapidly decompose and may be reincorporated into soil where they enhance soil structure, and larger quantities could be burned without excessive toxic impacts.[12] Given the ease with which single use items made from plant materials, including hygienic food wrappings, bags, straws, and longer-lasting artefacts such as umbrellas, floor coverings, fans, hats, brushes and backpacks, decompose in an equatorial tropical climate, the cultural problem of plastic is that its durability is in sharp contrast to the materials it has replaced. Hence 
there is a stronger cultural lag in envisaging dangers from plastics, and especially informal disposal of plastic in domestic fires, or into streams and ditches, in rapidly urbanising but still strongly agricultural tropical countries than in temperate ones. This is arguably evidenced by the statistics on relative rates of management, or mismanagement, of plastic waste, between tropical and temperate nations. [13] But it must also be noted that the first developed industrial nations, apart from the southern United States, are located in temperate zones. Further, in these nations the plastics revolution, which took off at scale in the 1970s, displaced other industrially produced materials which were also non-compostable, including pottery, metals, and glass, widespread use of which had already occasioned the development of mechanical and largescale waste disposal infrastructure before they were replaced with plastics. The tropical-temperate mix of the USA might then indicate why the USA has such markedly lower recycling rates than temperate European nations such as Germany and Sweden. But there are other, perhaps stronger explanatory factors, prominent among which is the matter of trust in cooperative and collective action among householders and businesses which is much higher in continental Europe than in the USA, so the possibility of a tropical cultural lag calls for further investigation.[14]
There is a second significant reason for the extent of mismanagement of waste disposal in Indonesia, and this concerns the highly centralised form of government - and especially tax collection - that characterises this extensive populous archipelago, and, related to this, the broader issue of collective action. Though the nation claimed its independence from a multicentennial Dutch colonial regime in 1945 - and finally ousted remnants of Dutch rule after a four year struggle in 1949 - Indonesia has nonetheless retained a notable feature of the Dutch colonial extractive economic model which was centred on the ability of Dutch District Officers to return revenues to Jakarta from the huge numbers of agricultural and fishing villages across the archipelago. At Independence Jakarta retained this highly centralising and extractive model of economic organisation with the consequence that the Jakarta government and bureaucracy, and the dominant business agencies of Indonesia, including many publicprivate partnerships, function as an economic 'core' which draws resources from a vast periphery. This model of resource extraction means that citizens and communities that are 'peripheralised' in developmental terms bear the social costs of rapid development of natural resources and of industrial transformations of production - such as the shift to plastic - while 
Jakartan agencies both public and private in the developmental core in the main reap the benefits, many of which, particularly during the post-1967 regime of President Suharto, were subject to corrupt elite capture and ended up offshore.[15]

The extent of elite capture of Indonesian wealth led ultimately to the overthrow of the Suharto regime in 1998 in a popular uprising and the successor administration undertook a major program of political reform, known as Reformasi, in which more political power was devolved to Provinces across the archipelago. But, despite this, economic resources, and in particular taxes from businesses and from employment, are still collected centrally by Jakarta with only meagre resources handed back to the Provinces for the range of activities for which they are responsible, including waste management. Reformasi did involve recognition of the weakness of Provinces relative to Jakarta, and, under pressure from the World Bank, resulted in new laws giving greater responsibilities to the Provinces, and Districts, including on waste management as most recently recodified in Indonesian regulation Number 18 of 2008 Regarding Waste Management. This regulation requires all regions of Indonesia to have 'integrated waste processing sites where collection, sorting, recycling, handling and final waste processing takes place' and to ensure final disposal is in 'sanitary' landfills.[16] The new regulation gives greater responsibility to Provinces and Districts, but it also recognises the existing primarily informal character of waste collection in Indonesia and so requires Districts, kampungs, and households to organise waste sorting, collection and transportation, while the Province is only responsible for maintaining landfill/dump sites.[17] However, the law neglects the reality that this combination of informal sorting and landfill is not working properly, and that without adequate economic as well as political decentralisation, the Provinces, and Districts within them, have insufficient resources to establish and maintain waste management procedures of the kind that are well established elsewhere, including a number of Indonesia's neighbouring Southeast Asian nations. This situation has meant that as awareness of the problem of waste mismanagement has grown, initiatives to address it have come first from local communities themselves, or from Non-Governmental Organisations, and not from governmental agencies.

There is a third cluster of issues concerning collective action and trust in public action and governmental institutions, which are central to the broader problem of waste recycling, especially at the household and small business level whence most 'postconsumer waste' originates and which 
predominates in ocean plastic debris. Indonesia's post-colonial history of centralisation of benefits of resource extraction, combined with corruption, does not augur well for public confidence in government institutions and public action. We have already noted that low trust in governmental institutions and public collective action in the United States is a cultural factor in its low rates of recycling relative to most European nations. But Indonesia is much more communitarian than either the United States or Europe in the way it is organised at local level and in its culture more broadly. The Indonesian government recognises just over 69,000 kampungs (villages) throughout the archipelago - a pattern of organisation which persists in urban as well as rural areas - all of which are organised into Rukun Tetangga, which is the smallest unit of neighborhood, and the head of which is Ketua RT, or, colloquially, "Pak RT". And in these villages - including in urban areas neighbouring householders interact more frequently than is typical of either cities or smaller settlements in developed countries. This is evident most notably in the regular involvement of householders in communitybased activities such as gatherings at mosques, churches and temples, and in communal activities such as the abovementioned gotong royong which are often arranged at monthly or bi-monthly meetings of villagers with the RT. If, as Harring et al suggest[18], recycling is at root a collective action dilemma, since it requires the cooperation of individuals in private locations such as houses and small offices who receive no individually-targeted benefits for the regular performance of activities involved in waste sorting, then a nation such as Indonesia where there are relatively high levels of knowledge and trust between households, even if trust in central government is low, may be said to have a cultural 'resource' for addressing the problem that more developed, but individualistic, nations lack.

In the remainder of this paper we explore this third issue, namely the collective action dilemma, and the potential resource of Indonesian, religiously under-written, communitarianism in addressing it, through the lens of a case study of a local community initiative in the town of Ubud on the island of Bali. Ubud has grown from a small community set among rice fields in the south central part of the island of Bali into a sprawling and increasingly polluted town due to the dramatic expansion of tourism that has occurred on Bali since the 1980s. There are annually 2.5 million tourist arrivals to the international airport at Denpasar in South Bali, the majority drawn to the beaches close to the airport including Nusa Dua, Kuta, Sanur and Seminyak which are favourite holiday and 
retirement destinations of Australians since they offer year-round surfing and sunshine.

Ubud first became internationally known as an artistic and cultural centre because of the community of artists that was drawn to the area by the Russian born German artist Walter Spies who established a studio in Ubud in the 1930s. Ubud began to grow as a major tourist destination from the 1970s, particularly for tourists looking for cultural experiences such as Balinese dance and art galleries. A significant expansion in tourist arrivals to Ubud occurred in the years following the publication in 2006 of the autobiographical Eat, Pray, Love, and movie of the same name, in which the American author Elizabeth Gilbert describes a journey of self-discovery which led her to live in an ashram in Ubud.[19] Many of those who now visit Ubud are looking for some mix of exotic culture and spiritual therapy of the kind Gilbert winningly describes. But what they find is a town increasingly clogged with motorcycles, and with polluted air and waterways. And the surrounding and aesthetically appealing rice terraces are gradually being incorporated into an expanding built environment, and related services including rubbish deposition. Significant quantities of plastic waste - primarily from food and drink packaging - are deposited into ditches and streams around the town, burned in backyards, or dumped on vacant patches of land close to the town. The author has seen plastic buried in soils on rice paddy around Ubud, while the rainy season washes considerable quantities of plastic from Ubud's water-catchment into the ocean to the south.

To cater to the huge tourist influx, Ubud, and Gianyar Province in which it is situated, now have over 2000 hotels, guest houses and 'losmen'. Tourist businesses market themselves by referencing Bali's cultural and spiritual beauty and heritage but in practice they are major contributors to environmental problems, including the generation of volumes of waste - and in particular of plastic related to food and drink which are overwhelming Bali's informal waste gathering systems and hence its rivers and beaches. It was in the hotel sector that concerted efforts were first made to address the growing problem of plastic and other waste. The first projects focused on Ubud hotels from 1993-9 but were ultimately unsuccessful for a range of reasons including the informal nature of waste collection in Indonesia and obstacles in local political and commercial networks. [20] These projects had their origins in the Yayasan Wisnu Foundation (Wisnu Foundation/YW) which went on to organise a more successful waste sorting program in the tourist area of Nusa Dua with the largest hotels, and a commercial waste business, from 1996. The project involved training the hotels 
in reducing and sorting their waste so that after collection from the hotels it could be further sorted into waste food that is subsequently sold as pig food, plastics which are shipped to Surabaya for recycling, and compost which goes back to the hotels for use on their gardens. Informal studies claim that for the hotels concerned the project resulted in an $80 \%$ reduction in waste tonnage going to landfill.[21]

Yayasan Wisnu was formed by a growing middle class of Balinese people in Ubud and Denpasar who had become concerned at the contradiction between the Hindu religion and customs of Bali and its increasingly toxic environment. YW's website indicates they adopted the name Wisnu after the Hindu deity responsible for the preservation and maintenance of life. [22] This points to a more deep seated dialectic between the tourist-related environmental desecration of Bali and Balinese Hindu beliefs, customs and practices concerning the circular flows of birth, maturation, death, decay, renewal and rebirth that encompasses everything from the tops of mountains to the rice terraces and river outflows into the sea and as vividly displayed in modern Balinese landscape painting. [23] Rituals sustain the lifecycle by cleansing habitat, houses, land and temples of biological and human wastes that might block the positive flow of life and so pollute - physically and/or spiritually - the bodies and spirits of
Hindus. As MacRae argues,

(the) cultural dichotomy of purity/ impurity' is central to Balinese religious beliefs and practices and in particular in the way Balinese engage with a host of invisible beings, especially ancestors and the natural world. The resulting amalgam includes a pervasive symbology of pollutions created largely by biological processes such as leakage or excretion of bodily substances or waste, sexual activity, menstruation, birth, sickness and most of all death.[24]

In Bali the activity of managing waste is focused in particular on household and temple spaces, and specifically on sweeping potentially polluting material from them into the surrounding environment where it is 'free' to be recycled by the other beings that inhabit the land. At the same time offerings are made on the borders and especially at the entrances to dwellings and temples to cleanse the boundary of sacred/profane spaces. Offerings at the border have the function of diverting potentially undesirable influences from entering in, whether these be the spirits of the dead or more prosaic beings such as ants, while also encouraging good and favourable spirits to look pleasingly on the beings within.[25]

The most important ontological boundary in Balinese Hinduism involves the border between life and death, around which customs have clustered which point in a particular way to the broader problem of waste, decay and their potential to pollute and 'block' life generation and renewal. 
Hindu practice regarding cremation, and the huge resources of time and money devoted to periodic collective cremation rituals, manifests a deep cyclical theology in Balinese Hinduism which connects all life, all being, all matter and all organisms with the divine. But this central role of fire in enabling spirits to escape the death and decay of the body and return to the karmic cycle of rebirth may also play a role in promoting the burning of rubbish as a preferred mode of disposal. The fire one often sees, and smells, in Balinese and Javanese streets in the evening is a little 'sacred' fire. But because of plastic and other toxic ingredients of modern consumer products these fires of spiritual cleansing of decaying matter pollute living beings rather than protecting them from unwanted influences.

Mary Douglas was among the first modern anthropologists to consider the evolved role of religion in dealing with issues of purity, pollution, and waste. She argued that the cultural roles of religious beliefs and practices in regulating human diet, hygiene and waste, and in dividing between purity and pollution, permitted and taboo, are central to the dietary, ritual and ethical rules and customs of many religious traditions including that of the ancient Hebrews, a theory that she elaborated more extensively in a later commentary on the book of Leviticus.[26] The cultural influence of these ancient practices remains extensive, though hidden in plain sight, in Indonesia. The practice of male circumcision which was first adopted by the Hebrews, and later by Muslims, is believed to 'cleanse' or hallow the male reproductive and excretory organ, while the practices of kosher, and halal, slaughter of animals involves a strict rule about how to deal with waste blood. Both practices are intrinsically connected with the protection and separation of life from waste. And both practices were taken up by Muslims who are the majority religion (87\%) of the Indonesian archipelago. The requirement to return the blood of animals to the ground during slaughter originates in part in the ancient Hebrew belief that the 'life-blood' (in Hebrew nephesh) of humans and other animals is the divine spirit which animates all breathing beings. Killing animals in a way that does not honour the life blood therefore potentially desecrates the intrinsic animal-human-divine nexus of being. As Klaus Eder argues, kosher, and later halal, slaughter requirement therefore resolve the danger of infection (by violence) of the act of killing since it is only performed in certain specially hallowed places and by a separated class of people.[27] And it resolves the threat to the sacredness of life by returning the life-blood to the earth because 'the Earth is the Lord's and the fullness thereof' (Psalm 24.1).

Douglas' and Eder's 
anthropological theorisations of dietary laws point to their potential relation to modern pollution issues, including the potential role of religion as a cultural resource for re-imagining the production-waste cycle in the multireligious cities, towns, rural and coastal areas of the Indonesian archipelago. This is particularly important in Indonesia since evidence points to the superiority of informal networks over centralised rubbish collection systems in many parts of the archipelago, including Bali, where a large-scale proposed 'waste to energy' project attracted extensive backing and funding from authorities in Bali and Jakarta, and from Indonesian and international businesses and agencies but is still not in operation more than ten years after conception. [28] The potential role in Indonesia of religiously engaged local communities in sorting waste, in commissioning its safe exit from homes, businesses, streets and rivers, and in guarding against those careless forms of waste disposal including not only fires but the frequent dumping of bags of waste in ditches and on road sides - through communitarian and moral effort therefore needs further investigation and it is to that end that we now turn in more detail to the case of Ubud waste including Rumah Kompos.

The second round of efforts to address Ubud's growing waste problem, after the failure of the above mentioned efforts, commenced in 2008 when expatriate members of the Ubud Rotary
Club, together with the new NGO Bali Fokus, came up with a plan to divert and recycle $10 \%$ of the 50 tonnes of waste that is dumped at a huge landfill and waste 'mountain' at Gianyar to the west of Ubud near the coast. The landfill emits methane and the project was designed in such a way as to obtain funding from the Clean Development Mechanism (CDM) United Nations Framework Convention on Climate Change (UNFCCC) since the project would reduce methane emissions from the dump and these have a global warming potency 20 times that of Carbon Dioxide. The project proposal was submitted and funds from the CDM were utilised in 2008 to build a recycling and composting facility at Temesi close to the landfill. However it was difficult to persuade Balinese to work in the facility since Balinese Hindus regard waste sorting as a spiritually polluting activity. Eventually Javanese Muslims were hired and the project known as Temesi Recycling has continued in operation since then. [29] It also runs an education center in order to teach children and students about the importance of careful waste management. One obstacle to a funding model that does not rely on overseas payments from the CDM is that of the two saleable products - plastic and compost - compost is not much used by Balinese who instead use nitrogen fertilisers in rice cultivation which, despite their negative effects on soil 
quality, are heavily subsidised - at 90

percent of cost - by the Indonesian government which regards food security as a national priority.

A third attempt to resolve Ubud's still growing waste problems was commenced in 2011 in the kampung of Padang Tegal in central Ubud. Supardi Asmorobangun is the manager of the waste project in Padang Tegal and describes how it grew out of the Padang Tegal adat (customary) association and its Trinity of subdivisions which, like all Balinese villages, incudes a Baga Parahyangan - a group concerned with the divine, headed by the Priest which oversees rituals and the Temple; a Baga Pawongan concerned with people matters including heath, rice growing and other economic activities; and a Baga Palemahan that deals with habitat or environment, including land, waste and water issues. In 2011 the Baga Palemahan was led by Adana who built the Yoga Barn in Ubud and runs an organic farm. Adana investigated means to address the waste problem in the village by researching initiatives in Javanese cities and identified a project in Yogyakarta called Rumah Kompos (RK) which draws waste from households and businesses and educates its clients in the rationale and methods for sorting waste. Adana then asked Supardi to produce three illustrated booklets for the villagers on the problem of plastic waste; the rationale for waste recycling; and how to sort waste before it is collected to improve recycling rates.

In 2012 Adana and the Baga Palemahan members then wrote a business plan to purchase a waste truck and rent a building to sort the rubbish and recycle as much as possible. The village has the largest income of any in Bali because the Monkey Forest Sanctuary land belongs to the village so they receive revenues from visitors. They finally got the agreement of the village and hired Supardi to run the project in 2014. Supardi began educational outreach to schools and hotels which are the largest institutions in the area and by 2015 they had achieved 60 per cent compliance in careful waste sorting. But this did not meet the goal of the project which is that all the households and businesses which are clients of Rumah Kompos commit to sorting their waste so that the two waste streams - of organic and inorganic material - are reliably and consistently separated before collection. RK serves 671 residences and 600 businesses.

Big businesses, which are mainly hotels and large restaurants, pay RK from 600,000 to 2-3 million rupiah, and small businesses and households pay 85000 rupiah a month. These fees cover salaries and operating costs but only with full compliance in waste separation. This is first because careful separation provides a stream of compostable material that can be 
directly uplifted and deposited by mechanical truck onto a conveyor belt leading to the composting shredder that turn it into material ready for aerobic composting in the Rumah Kompos facility. Secondly, careful separation maximises the value of other materials in the process, and especially plastic and paper, both of which are shipped to Surabaya for recycling. Thirdly, careful separation minimises contaminated and unrecyclable mixed waste that has to go to landfill.

To raise the compliance rate, Supardi and Adana held community meetings, and workshops in schools and hotels, to explain the project's aims. And they used a range of media at these meetings including wayang kulit shows (traditional Javanese-style shadow puppets); powerpoint presentations by invited experts from the Hindu University and NGOs in Denpasar; and short video documentaries. All were designed to expose the health, ecological and economic (including tourist-related) problems arising from poor disposal and sorting of waste in Ubud. But even after all these interventions, a number of householders remained steadfastly non-compliant.

In order to raise the performance of consistent non-compliers, in $2016 \mathrm{RK}$ numbered all the waste receptacles and RK staff began a spreadsheet in which waste from poorly sorted receptacles was tracked. RK then created a performance league table name households and businesses, with the most compliant at the top and the least compliant at the bottom. The table was then regularly posted to all RK clients on social media. The use of publicity in the community significantly increased compliance and by this point RK was achieving $90 \%$ compliance in careful waste separation. But there remained a stubborn $10 \%$ of male householders who refused to comply.[30] Supardi then discussed the list of the remaining non-compliers with the Temple Priest, and the heads of the three baga. The heads of the baga then issue a letter to the non-compliant households indicating that they would in future only receive RK services if they separated their waste. The letter was also shared at the village meeting. With the authority of this letter, Supardi then instructed his staff to stop collecting waste from the worst performing households. There were however a number of incidents in the first week of the new procedure. The rubbish that was uncollected began to smell. And the householders whose rubbish was uncollected issued threats to Supardi by telephone or on social media. There was also one violent incident. A male householder kicked his household rubbish receptacle from height so that its contents fell on RK staff during a nightly collection round. [31] After this violent incident, RK staff were scared and insisted Supardi drove the truck on all nightly collection rounds. Seeing that he and RK remained 
steadfast, non-compliant households eventually gave in and began to properly sort their waste, and the project achieved 100 per cent compliance in waste sorting within a few weeks of the issuance of the letter from the village baga heads.

In 2017 RK determined that to achieve its aim of generating a significant and saleable stream of compost it needed a formal piece of infrastructure to facilitate this. Given the limited funds available at Province and District level the only way to achieve this was through government ministries in Jakarta. An initial approach was made to the Ministry of the Environment and Tourism who were impressed with RK bit did not have the needed infrastructure funds. Instead they proposed RK approach the Ministry of Public Works who sent two civil servants to visit RK. During their visit they expressed scepticism at the claim that RK was achieving $100 \%$ waste sorting compliance so they visited some of the householders themselves and found that the householders were indeed in full compliance and were happy with the procedure and the service from RK. After that the Ministry encouraged RK to apply to Jakarta for competitive funds - competitions for Ministry public works projects are held annually at Provincial level - to develop the needed infrastructure. The proposal RK wrote for the fund won first place in the Province competition in 2017, and in 2018-19 a substantial two storey building was constructed on the edge of the Monkey Forest Sanctuary car park containing 50 four by four metre aerobic composting hoppers, mechanical shredders, waste sorting areas, office accommodation, and a public auditorium for educational events.

At time of writing, RK is sharing its waste sorting philosophy and program with other communities in and beyond Bali, and it has begun to attract international funders. The McKinsey Foundation, from its offices in London and Manhattan, visited RK in 2018 and opened an office in Sanur to address Bali's waste problem. McKinsey is now working with Supardi to roll out the RK waste management model in other communities in Bali. Work has begun to initiate two RK-style community waste management programs in the communities of the Bedugul and Besakih Temples. Both Temples are popular with tourists as well as important pilgrimage sites for Balinese and hence make ideal locations for publicising and spreading the RK waste management approach to other parts of Bali and beyond.

In interviews with Supardi, and with Adana, they both describe the motive philosophy behind RK as arising from Balinese Hindu beliefs about the cyclical nature of all life, and the related belief that everything in the universe is a manifestation of the gods/goddesses. 
Supardi expressed this as follows:

I learned Hinduism among others from the Temple priest in this community and we explain the concept of composting through Hindu philosophy which we say is like the Trinity. Brahma is the Creator, Wisnu is the Preserver, and Siva is the 'destroyer' as some people call him, but think of it like this. Who creates you is Brahma. When you grow up your parent is like Wisnu, who gives you food and nurtures you, and when you die it is Siva who receives your body and 'recycles' it so you are returned to the cycle of rebirth.[32]

As previously discussed, Douglas and Eder, from different theoretical perspectives, argue that there is an intrinsic relationship between traditional religious customs and rituals concerning the boundary between permitted and unpermitted, sacred and profane, and dietary and hygiene rules, including rules governing relationships with other animals and habitat, and rules governing the regulation of waste fluids and materials in everyday life. However the contemporary relationship between rubbish and religion is underinvestigated in the scientific literature on waste management. In the case study of Rumah Kompos we find empirical evidence that demonstrates that religion is a potential and effective source of social and communitarian regulation concerning rubbish and recycling. We summarise the outcomes of the RK case study as follows, recognising that this is a single case study albeit situated in a narrative of a larger set of attempts to address waste management problems over more than twenty years in Bali and Ubud:

1. Dividing materials and substances between polluted and permitted is an intrinsic part of daily and seasonal devotion because every householder and business has a moral and spiritual duty to find a right relation to the divine cycle of life and death because the divine runs through all things.

2. In modern consumer societies, religious duties have become detached from contemporary forms of business and household waste generation. This is partly because new materials - and especially plastics and other synthetic materials - do not breakdown in the normal processes of household consumption and waste clearing and represent a cultural development that has yet to be assimilated into traditional pollution and hygiene rules.

3. Rumah Kompos used the social capital of Indonesian, and more especially Balinese, communitarianism to generate an unusually high level of compliance in business and household waste separation and hence a waste management stream that is highly amenable to at least two of the three R's of Reduce, Reuse and Recycle, since it converts the majority of waste by weight either into compost or into saleable recyclable materials. 
4. Rumah Kompos takes as its theological inspiration two features of Balinese Hinduism: first, the importance of rituals which maintain and 'clean' the crucial ontological boundaries between sacred and profane, good and evil, life and death: and second, the Trinitarian ontology of Brahma as Creator, Wisnu as Sustainer, and Siva as Eliminator. These two theological ideas helped both to inspire and to provide legitimation for a new social construction of household and business consumption and waste handling in RK. Hence the idea of the circular economy in which waste is recycled as material for succeeding rounds of production finds theological legitimation in the divine cycle of birth, death and rebirth which Balinese believe governs the journey of all beings on Earth, and not only humans, from birth to rebirth.

Bali is a highly religious society where it is estimated that Hindu households devote approximately one quarter of their annual waking hours to the performance of religious rituals of various kinds. The RK case study demonstrates that the communitarian culture that such extensive religious participation entails acts as a source of social capital which was mobilised by RK staff, and the Baga heads of
Padang Tegal, to achieve an exceptional level compliance of households and businesses in the practice of waste sorting. This feature of Balinese society is to a lesser extent a feature of the multiple religious identities and cultures of Indonesia, including those of its majority Muslim population. Indonesia is among the most actively religious nations on earth.[33] Religion throughout the Indonesian Archipelago regulates the daily, annual and life-long temporal, spatial and communitarian habitat of citizens, households and communities in urban and rural areas. In support of this claim, we note that in the Javanese cities of Yogyakarta and Solo, Muslim- and Christian-led kampungs visited by the author have sponsored waste sorting and recycling initiatives analogous to those of Rumah Kompos, albeit with lower compliance rates and without the infrastructure investment from Jakarta that RK was able to attract.[34] We also note the emergence of 'eco-pesantren' among the many hundreds of Islamic boarding schools in Java and Sumatra and that these eco-pesantren foreground their ecological credentials by highlighting most of all their commitments to the three R's of rubbish reduction, recycling and reuse. In conclusion, we propose that the RK case study demonstrates that religion in general, and not only Balinese Hinduism, has the potential to contribute to a broader, communityoriginated but State-supported, solution 
to Indonesia's waste management problem. We also propose that, given the concerning and intractable extent of Indonesia's rubbish problem, and its impacts on the health of Indonesians and of their surrounding ecosystems and habitats, and beyond Indonesia on the maritime region of Southeast Asia, that this is a matter for urgent further research by scholars of waste management, and of religions, in Indonesia.[35]

\section{References}

[1] Jenna R. Jambeck, Roland Geyer, and Chris Wilcox et al, 'Plastic waste inputs from land into the ocean,' Science 347 (2015) 768-771.

[2] 'Peraturan Presiden Republik Indonesia, Nomor 83, Tahun 2018, Tentang Penanganan Sampah Laut, Dengan Rahmat Tahun Yang Maha ESA, Presiden Republik Indonesia, ttd. Joko Widodo, 21 September 2018.' at https://sipuu.setkab.go.id/PUUdoc/175608/ Perpres\%20Nomor\%2083\%20Tahun\%202018.pdf accessed 229 February 2020.

[3] Shunsuke Sasaki, Tetsuya Araki, Armansyah Halomoan Tambunan, and Heru Prasadja, 'Household income, living and working conditions of dumpsite waste pickers in Bantar Gebang: Toward integrated waste management in Indonesia.' Resources, Conservation and Recycling 89 (2014) 11-21.

[4] On the role of scavengers and the payments they receive per kilogram of waste see further Janeen Tang, 'A Case Study of a Hotel Solid Waste Management Program in Bali, Indonesia.' MSc Thesis, University of Waterloo, Canada, 2004, 50-1.

[5] Rinku Verma, K. S. Vinoda et al, 'Toxic Pollutants from Plastic Waste - A Review.' Procedia: Environmental Sciences 35 (2016), 701-8.

[6] Verma, Vinoda et al, 'Toxic Pollutants from Plastic Waste.' 704.

[7] Roland Geyer, Jenna R. Jambeck, and Kara Lavender Law, 'Production, use, and fate of all plastics ever made.' Science Advances 3 (2017) e1700782.

[8] Simonetta Falasca-Zamponi, Waste and Consumption: Capitalism, the Environment and the Life of Things. New York, Routledge 2011.

[9] Pope Francis, Laudato 'Si: On Care for Our Common Home. Rome, Vatican City, 2015.

[10] On the multiple meanings, and potential viability, of the concept of the 'circular economy' see Julian Kirchherr, Denise Reiker and Marko Hekkert, 'Conceptualising the circular economy: an analysis of 114 definitions.' Resources, Conservation \& Recycling 127 (2017) 221-32: for a broader look at the history, including the archaeology, of waste see John Scanlan, On Garbage. London, Reaktion Books, 2005.

[11] See again Falasca-Zamponi, Waste and Consumption and Scanlon, On Garbage.

[12] Graeme MacRae, 'Solid waste management in tropical Asia: what can we learn from Bali?' Waste Management \& Research 30 (2012) 72-9.

[13] Janbeck et al, 'Plastic waste inputs from land into the ocean.' But as already indicated temperate nations industrialised first, and had more waste infrastructure before the plastics revolution, so there is need for further investigation of this question.

[14] For a comparison of attitudes and arrangements concerning recycling in the USA 
and Germany see James E. Donnelly, 'Numbers never lie, but what do they say?: A comparative look at municipal solid waste recycling in the United States and Germany.' Georgetown International Environmental Law Review 15 (2002) 29-52: on recycling as a collective action problem, and related issues of trust in public action, see further Niklas Harring, Sverker C. Jagers, and Frida Nilsson. 'Recycling as a large-scale collective action dilemma: A cross-country study on trust and reported recycling behaviour.' Resources, Conservation and Recycling 140 (2019), 85 - 90.

[15] The 'core-periphery' description of post-colonial development was first presented in Andre Gunder Frank, Capitalism and Underdevelopment in Latin America. New York, Monthly Review Press, 1967; Frank, with Immanuel Wallerstein, then developed 'World System Theory': it attracts criticism, particularly from Northern hemisphere economists and social scientists, but it is still evident in the ongoing extraction of natural resource wealth, and flows of funds, from formerly colonised to former colonising nations in the world economy at the present time: see further Andre Gunder Frank, 'A theoretical introduction to 5,000 years of World System History.' Review XIII (1990), 155 - 248. Indonesia's post-independence President Sukarno was a prominent critic of the postcolonial development model and under Sukarno Indonesia developed barriers to external wealth extraction, including a ban on ownership of land and licensed road vehicles by non-Indonesians, which remains in place. But the core-periphery model has relevance to the problem of waste management and other environmental costs of an extractive economic model not so much externally but internally in post-colonial Indonesia.

[16] Republic of Indonesia, 2008. Act of the Republic of Indonesia - Number 18 - Regarding Waste Management. at http://www.vertic. org/media/National\%20Legislation/Indonesia/ ID_Waste_Management_Act_2008.pdf accessed 6 March 2020, and cited by Christian

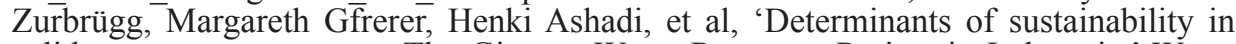
solid waste management - The Gianyar Waste Recovery Project in Indonesia.' Waste Management 32 2012, 2126-33.

[17] Amelia Bruce and Donovan Storey, 'Networks of Waste: Informal Economic Systems and Sustainability in Bali, Indonesia.' Local Economy 3, 2010, 176-89.

[18] Harring et al, 'Recycling as a large-scale collective action dilemma'; see also T. Smallbone, 'How can domestic households become part of the solution to England's recycling problems?’ Business Strategy and the Environment 14 (2005), 110-122.

[19] Elizabeth Gilbert, Eat, Pray, Love: One Woman's Search for Everything Across Italy, India and Indonesia, New York, Viking, 2006.

[20] MacRae, 'Solid waste management in tropical Asia.'

[21] Martin Medina, 'Composting and recycling in Bali', Biocycle, (August 2009), 41-2 and PT. Jimbaran Lestari (2010) at: http://www.jimbaranlestari.org visited 6 March 2020.

[22] MacRae, 'Solid waste management in tropical Asia.' 73 and http://www.wisnu.or.id/id/ accessed 4 March 2020.

[23] MacRae, 'Solid waste management in tropical Asia.' 73.

[24] MacRae, 'Solid waste management in tropical Asia.' 74.

[25] On the role of offerings in drawing creatures away from Balinese dwelling spaces see David Abram, The Spell of the Sensuous: Perception and Language in a More Than Human World. New York, Vintage, 1996.

[26] Mary Douglas, Purity and Danger: An Analysis of Concepts of Pollution and Taboo, London, Routledge, 1966 and Mary Douglas, Leviticus as Literature, Oxford, Oxford University Press, 1999: see also Jonathan Klawans, 'Review essay: rethinking Leviticus and rereading Purity and Danger.' Association for Jewish Studies Review, 27, 2003, 89102.

[27] On the eco-social significance of Jewish, and later Muslim, dietary laws around animals 
and blood see further Klaus Eder, The Social Construction of Nature: A Sociology of Ecological Enlightenment, Eng. Trans. Mark Ritter, London, Sage, 1996.

[28] Bruce and Storey, 'Networks of Waste' and MacRae, 'Solid waste management in tropical Asia.'

[29] Graeme MacRae and Ljiljana Rodic, 'The weak link in waste management in tropical Asia? Solid waste collection in Bali.' Habitat International 50, 2015, 310-316.

[30] Bali is a patrilineal society in which the norm is for a household not to be headed by a man: single, divorced or widowed women are customarily expected to reside in the compound of their parents. Traditional Balinese homes consist of a compound with a number of small dwellings rather than one house with multiple rooms. Households headed by women, and multi-roomed dwellings, are now becoming more common, in part because of a considerable influx of foreign residents and the emergence of touristrelated businesses in which women as well as men take leadership roles: see further Frederik Barth, Balinese Worlds Chiacgo, University of Chicago Press, 1993, 36-8 .

[31] Public violence is contrary to the behavioural norms of Balinese religious culture but when expressed it is more likely to be seen as legitimate when initiated by a party who believes they have been wronged: see further L. E. A. Howe, 'Gods, peoples, spirits and witches: the Balinese system of person definition,' Bijdragen tot de Taal-, Land-en Volkenkunde Deel 140, 2/3sw Afl. (1984), 193 - 222.

[32] Supardi Asmorobangun, interview with Michael Northcott, Rumah Kompos, Monkey Forest Sanctuary Car Park, Ubud, 20 October, 2019.

[33] For a contemporary survey of the extent and social significance of religiosity in Indonesia see further Bernie T. Adeney-Risakotta, Living in a Sacred Cosmos: Indonesia and the Future of Islam, New Haven, CT, Yale Southeast Asian Studies, 2018 and Robert W. Hefner, 'The religious field: plural legacies and contemporary contestations' in Robert W. Hefner (ed.) Routledge Handbook of Contemporary Indonesia, London and New York, 2018, 211-225.

[34] On research on religious communities and recycling beyond Indonesia see Zeeda Fatimah Mohamad, Noshahzila Idris, Azizan Baharuddin, Amran Muhammad, Nik Meriam Nik Sulaiman, 'The role of religious community in recycling: empirical insights from Malaysia.' Resources, Conservation and Recycling 58 (2012), 143-151; and Jeremy Kidwell, Franklin Ginn, Michael Northcott, Elizabeth Bomberg, Alice Hague, 'Christian climate care: slow change, modesty and eco-theo-citizenship’ Geo 5 (2018), e00059.

[35] Research for this paper was supported by the Ford Foundation (Indonesia), Grant title: 'Co-designing Sustainable, Just and Smart Urban Living,' awarded to the Indonesian Consortium of Religious Studies, Universitas Gadja Madah, from 1 January 2019 to 31 December 2020. 